\title{
Exploratory Study on Agricultural Practices on the Bamboutos Mountains
}

\author{
Ngimdoh Marline Mirene, University of Dschang \\ Tchekote Herve, University of Dschang \\ Achamoh Victalice Ngimanang, University of Bamenda
}

\begin{abstract}
The paper intends to examine the logic of agricultural practices on upper slopes of the Bamboutos Mountainswhich cut across the South West, West and North West regions of Cameroon. The zone is located between latitude, $5^{\circ} 32^{\prime}$ and $5^{\circ} 51^{\prime} \mathrm{N}$, longitude, $9^{\circ} 56$ and $10^{\circ} 09^{\prime} \mathrm{E}$ and it extends from an altitude of $2000 \mathrm{~m}$ to $2700 \mathrm{~m}$. After developing a conceptual framework that reviews the key concepts and theories of agricultural practices. Both primary and secondary data were collected from the eight localities which constitute the area under study to collect data effectively from 162 respondents. Analysis was done with the help of SPSS,'1 Excels 2016 and the result is presented in tables, charts and graphs. Correlation and regression techniques are used. The results of the study revealed that Agricultural practices is the likelihood of the Bamboutos mountains dwellers. Majority of the respondents are male, age between 30-40 years, and holder of just FSLC.Farmers experience has positive and significant correlation with method of conserving farm products, types of farm tools used and applicability of chemicals but a weak rank correlation between crop rotation and level of education. Equally, crop rotation and mixed farming is significantly and positively influenced by education attainment of farmers. Five distinctive steps were identified for successful farming in the area like elsewhere. For the third objective of the article, a good number of problems plaguing the agricultural practice on the Bamboutos mountain were identified ranging from frequent farmergrazer conflict, insecurity, to more general problem as resistance of farmers to adapt to new techniques, expensive nature of farm input, poor farms to market roads, acute short of funds and personnels. Improving farms infrastructures, training and recruiting more personnels, reestablishing agricultural banks, and breaking land tenure obstacle among other strategies can go a long way to stimulate agricultural practice in the mountain area.
\end{abstract}

Keywords:- Agricultural Practices, Evolution and Challenges, Bamboutos Mountains.

\section{INTRODUCTION}

Agricultural practices are collection of principles to apply for farm production processes to facilitate farming and to get better agricultural products. On the Bamboutos Mountains, there has been a great change in the agricultural practices and techniques as the main actors are increase in size and spheres. In the past before the economic crises which saw the prices of main cash crops of the area which were rubusta coffee and Arabica coffee in the lower slopes of upper slopes of the mountains respectively, the main actors were farmers and Cooperative (CAPLAMI) who acted as buyers and the techniques use were characterized with the use of rudimentary tools.

Agricultural practices contribute immensely in sharpening socioeconomic life of the population. Poor agricultural practices mainly due to illiteracy and increasingly high population pressure of Bamboutus massif area has forced dwellers to farm on the steep slopes of the mountain, leading to erosion and further loss of fertility. In addition, the forest has witnessed rapid loss of its coverage due to increasing agricultural practices.

The post crises period also described as the post coffee era inflicted poverty to the population which push to find alternative activities which today has become a blessing as there was a population drift as reported in Ngoufo (1992) to the upper slopes of the mountains where market gardening and other crops are intensively cultivated nowadays. The intensity of the agricultural activities is this area has attracted the attention of many as the actors have extended to international level.

According to Wilfred et al, (2016), Cameroon has since early 1990s began spending billions of francs CFA to import large quantities of food items (rice, maize, onion, tomatoes, milk and poultry) even though relying on national products has a clear comparative advantage. This has been very worrisome as it undermines local production potentials and pushes many producers out of the production chain as a result of unfair competition. The challenges are numerous (but not impossible) including low levels of input. Studying the practices of agriculture on the Bamboutos caldera is thus imperative. 
This paper is therefore reserved to shed light to various agricultural practices and change. Specifically, the article sought to:

- Examine the evolution of agricultural practices on the BamboutosMountains

- Shed light on the various steps of agricultural practices cycle

- Explore the problems of agricultural practices

To accomplish these objectives the remainder of the paper is arranged as followed: Having introduced the paper in Section 1, Section2 focuseson conceptual and theoretical review, section 3 is reserved for brief methodology and section 4 is for presentation and discussion of result whereas section 5 conclude the article.

\section{CONCEPTUAL AND THEORETICAL REVIEW}

\section{Concept of Agriculture Practice}

Agricultural practices are collection of principles to apply for farm production processes to get better agricultural products. In other words, agriculture practices are simply techniques used in agriculture to facilitate farming. Plowing the soil is an agriculture practice, minimum tillage, free range raising of poultry, pigs and cattle rearing as well as organic farming and sustainable agriculture are equally considered as agricultural practices (Eva, 2017).

Etymologically, the word agriculture is a late Middle English adaptation of Latin agricultūra, from ager, "field", and cultūra, "cultivation" or "growing". Agriculture usually refers to human activities, although it is also observed in certain species of ant, termite and ambrosia beetle. To practice agriculture means to use natural resources to "produce commodities which maintain life, including food, fiber, forest products, horticultural crops, and their related services. This definition includes arable farming or agronomy, and horticulture, all terms for the growing of plants, animal husbandry and sometimes forestry.

Agriculture sector in Cameroon is amongst the main occupations for over $70 \%$ of citizens and contributes enormously to the country's economy (Wilfred. Abia, Conalius Shum, Richard Fomboh and Markjovert Ageh, 2016). The lack of access to adequate amounts of safe and nutritious food is a public health concern worldwide and particularly in Cameroon. Due to its agro-ecological diversity, Cameroon has great potentials for agricultural production to contribute towards its over 23 million people and beyond, thus contributing towards feeding the world's 9 billion people. Until the late 80s, Cameroon was considered self-sufficient in agricultural production and played a role of food garret for its neighbouring countries.

Eva (2017) identified five indigenous farming practices that have helped shape sustainable farming systems and practices all over the world highlighted in the celebration of the 10th Anniversary of Declaration on the Rights of Indigenous Peoples (UNDRIP), Food Tank included: Agroforestry, Crop Rotations, Mixed-/Intercropping, Polyculture, Water Harvesting.

Trend in agricultural practices has greatly been modified with the adoptions of modern technologies in agriculture like tractors and pump sets. Even the livestock production has been totally changed into industrial type of production from backyard system. Animals provide manure, food and income and are used for cultivation and transport economically. Different animals can be fed on farm wastes efficiently, which provide financial security at the time of distress. In Indian culture, cattle are treated as an integral part of the family. After undergoing the huge losses from adapting crossbred cows like Holstein, Frisien and Jersey, farmers are fast changing towards indigenous cattle, since their maintenance is cheaper and the male calves can be used for cultivation and transport.

Agriculture in most developing countries was an integrated cultivation of crops, animals and trees to meet most of the family and community needs rather than market. Trees played an important role in providing green manure, fodder, fruits, fuel and timber besides conserving soil water and hosting beneficial insects and birds. Now, it is necessary to revive the traditional knowledge on seed selection and preservation to bring back the self-reliance and seed availability at the time of sowing. Similarly, rural population is fast changing their medical treatments since synthetic drugs have become more expensive and found to create side effects. They now started growing medicinal plants like Neem, for medication of both humans and their livestock.

\section{Classification of agricultural practices}

Agriculture is one of the most widespread activities in the world, but it is not uniform throughout. There are a number of ways to classify agriculture, and some of the major criteria which can be adopted as noted by Dilip Chandra (2018), Syed Asif (2018), and Bouville, (2014) are as summarized in the following figure 


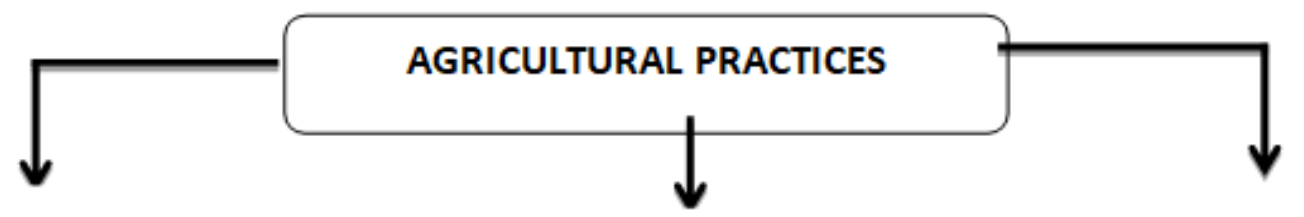

According to Types

(Dilip, 2018)

- Nomadic Herding

- Livestock Ranching

- Shifting Cultivation,

- Rudimentary Sedentary

- Tillage, Intensive

- Subsistence Farming

- Commercial Plantations

- Mediterranean Agriculture

- CommercialGrain Farming,

- Livestock and Grain Farming

- Specialized Horticulture

- Dairy Farming

- Subsistence Crop

- Stock Farming

- Dairy Farming
According to climatic conditions

(Syed, 2018)

- Subsistence Agriculture

- Extensive Agriculture

- Intensive Agriculture

- Plantation Agriculture

- Mixed Farming

Agriculture,

- Commercial Farming

Agriculture

Fig 1:- Classification of agricultural practices

Source: Adapted from Dilip (2018), Syed (2018) and Bouville, (2014)

Concept of Agricultural Techniques and methods

Modern agriculture depends heavily on engineering, technology and the biological and physical sciences. Irrigation, drainage, conservation and channeling are all important fields to guarantee success in agriculture and require the expertise of agricultural engineers. Agricultural chemistry deals with other issues vital to agriculture, such as the use of fertilizers, insecticides and fungicides, soil structure, analysis of agricultural products and the nutritional needs of farm animals.
Based on modern agricultural techniques, four criteria of classifying agriculture are evident (Syed-Asif, 2018). The first classification is on agriculture types based on water dependence, the second classification of agricultural techniques is in accordance to the scale of production and its relation to the market where two types are identified. The third category is in accordance to maximum or minimal production which has two sub types. Then, the fourth category based on method and objectives enable us to classified agriculture into traditional agriculture andindustrial agriculture.

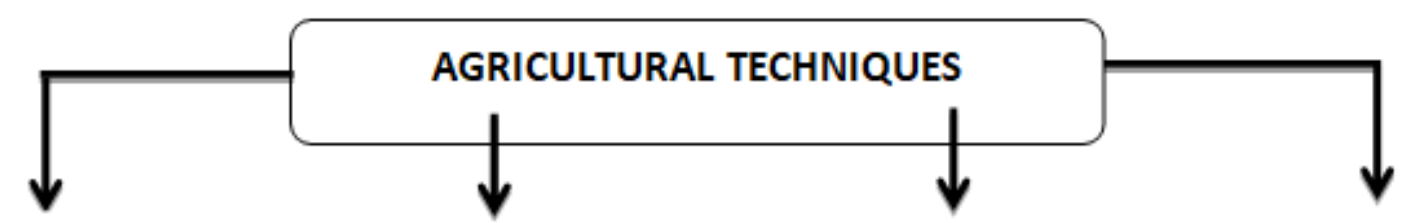

\begin{tabular}{|c|c|c|c|}
\hline $\begin{array}{c}\text { Water } \\
\text { dependence }\end{array}$ & $\begin{array}{c}\text { Scale of } \\
\text { production }\end{array}$ & $\begin{array}{l}\text { Intensity of } \\
\text { production }\end{array}$ & $\begin{array}{c}\text { Method/ } \\
\text { objectives }\end{array}$ \\
\hline - Dryland Farming & - Subsistence Farming & - IntensiveFarming & - Traditional Farming \\
\hline - Irrigation Farming & - Commercial Farming & - Extensive Farming & - Industrial Farming \\
\hline
\end{tabular}

Fig 2:- Classification of agricultural techniques Source: by the author adapted from Syed-Asif, (2018) 
Agriculture has been subjected to several changes over the recent years with causes linked to globalization, liberalization, Vertical coordination and Urbanization (Gerdien \& Roza, 2007). Globalisation is the increasing integration of economies around the world, particularly through trade and financial flows. The term sometimes also refers to the movement of people (labour) and knowledge (technology) across international borders. When a country liberalises its economy and trade policies, it can participate more easily in the international economy. Urbanisation has been increasing steadily over the past decades thereby increasing the market for agricultural (food) products reduces land dispute/pressure on rural land resource. These are very prominent on the Bamboutos Mountain as cultivable land is in acute shortages.

Another importance cause of change in agriculture is through vertical coordination. Swinnen and Maertens, (2006) iterated that new forms of vertical coordination (VC) have recently emerged, through private vertical coordination systems. Vertical coordination according to Swinnen and Maertens, (2006) take various forms, which can be thought of as institutional arrangements varying between the two extremes of spot markets exchanges (no coordination) to full ownership integration (full coordination).

Hazell, (2009) underlines that the boundaries between rural and urban areas are disappearing in many areas, as rural and urban areas are becoming increasingly integrated, not only geographically (with urban sprawl into rural areas) but also economically. The impact of HIV/AIDS like the recent outbreak of COVID 19 pandemic certainly has an increasing impact on many rural areas in developing countries and affecting agricultural production in these areas (Topouzis, 1999). These pandemic which are yet to be curable are increasingly becoming disastrous on agricultural activities in many developing countries with Cameroon inclusive. The impact of COVID 19 and AIDS on communities is deep and tragic. These pandemics like others often affect the active men and women and thus raise dependency ratio, lower the agricultural labour force, create unnecessary "stay home" holidays. (FAO, 2020).

Another problem of agriculture is linked to increasing limits to natural resource use. In many countries, the combination of population growth, a lack of technical development and ineffective allocation mechanisms have led to a rapidly decreasing availability of natural resources for many poor farmers. Soil fertility is still declining in many areas, due to a lack of nutrients (mineral or organic) of which the availability is impeded by imperfect markets or lack of purchasing power. Water is becoming increasingly scarce around the world, as water resources such as rivers are being increasingly used for different purposes, such as agriculture, hydro-power, or drinking water.

Ngoufo (1988) reported that in 1968, more than 50\% of the eastern slope of the Bambouto Mountain was occupied by grazing land and today only some rare relicts subsist in the upper zone of the massif. The high population pressure and the intensification of agricultural activities without any conservation measures in the upper part of this eastern slope may enhance degradation of soils in the area. The objective of this study is to evaluate the degradation rate and vulnerability potential of soils, and suggest ameliorative measures for improve soils productivity in the upper part of the eastern slope of the Bambouto Mountains.

According to Tsozué and Tamfuh (2016), Mounts Bambouto constitute the third largest volcano with approximate surface of 800 square kilometer of the Cameroon Line after Mounts Cameroon and Manengouba. This massif is situated between longitudes $09^{\circ} 33^{\prime} \mathrm{E}$ and $10^{\circ} 13^{\prime} \mathrm{E}$ and latitudes $05^{\circ} 30^{\prime} \mathrm{N}$ and $05^{\circ} 50^{\prime} \mathrm{N}$. Volcanic products of the massif are composed of basalts, basanites, trachytes, phonolites, rhyolites, tephrites, hawaiites, mugearites, tuffs and ignimbrites (Marzoli et al., 1999; Nono et al., 2004; Gountié et al., 2012), largely dominated by basalts and trachytes. Their ages range from $21.12 \mathrm{Ma}$ to $0.50 \mathrm{Ma}$ (Youmen et al., 2005; Nkouathio et al., 2008; Kagou Dongmo et al., 2010).

Tsozué and Tamfuh (2016), study area corresponds to the upper part of the eastern slope of this massif, above 1800 $\mathrm{m}$ of altitude. The climate, which is pseudotropical with temperate characteristics due to altitude (Morin, 1988), is fresh and humid, characterized by frequent mists and fogs which impede visibility. Temperatures vary from $1012^{\circ} \mathrm{C}$ and mean annual rainfall is $2507 \mathrm{~mm}$. Relief is uneven and natural vegetation is a lawn grass of Sporobolus prairies typical of temperate environments. This vegetation is strongly degraded by human activities. The main soil types identified in this part of the Bambouto Mountains are Andosols (Tematio et al., 2004; Tsozué et al., 2009).

\section{$>$ Evolution of agricultural practices on Bamboutos Mountains}

Agricultural and rural development has been the concern of countries in sub-Saharan Africa For several decades. According to Dufumier (1986), the important place of the agricultural sector in developing countries is justified by the fact that agriculture provides agri-food products and agricultural raw materials; help to bring a large amount of capital to other sectors of the economy; constitutes a labour pool; and has a large population which constitutes a potential market for industrial goods.

In Cameroon, since independence in 1960, the agricultural sector has been regarded as the foundation of the economy and the basis of its growth (Engola, 1984). Cameroon's agricultural economy has been built on export crops. In each region, the state has promoted a crop adapted from an agro-ecological point of view and intended for export. Until the mid-1980s, the development strategy for the agricultural sector was called "interventionist". In several regions of the country, the State had set up missions and development companies as well as agricultural cooperatives which were responsible for supplying rural areas with the means necessary for agricultural production and setting up infrastructure for marketing. and to improve living conditions in rural areas so as to limit the rural exodus of young people. 
The agriculture of the Western highland region of Cameroon where Bamboutos mountains is situated, was inclined in growing arabica coffee. In 1959, from local cooperatives, the State set up the Central Union of Agricultural Cooperatives of West Cameroon, UCCAO (Champaud, 1969; Courade et al, 1991) which was responsible for the supervision of coffee planters, mainly technical management, supply of agricultural inputs and marketing.

In total, Kuete and Dikoume(2000), already quoted, speaks of a recomposition against the background of decomposition of social life in the highlands of West Cameroon. Summarily, until the mid-1980s in West Cameroon, coffee was the main crop grown in the region. UCCAO, the departments of the Ministry of Agriculture and peasant leaders were the three main actors involved. With the coffee crisis, the economic crisis and its implications, farms are developing adaptation strategies, new players are emerging and old ones are changing, relations between stakeholders are changing.

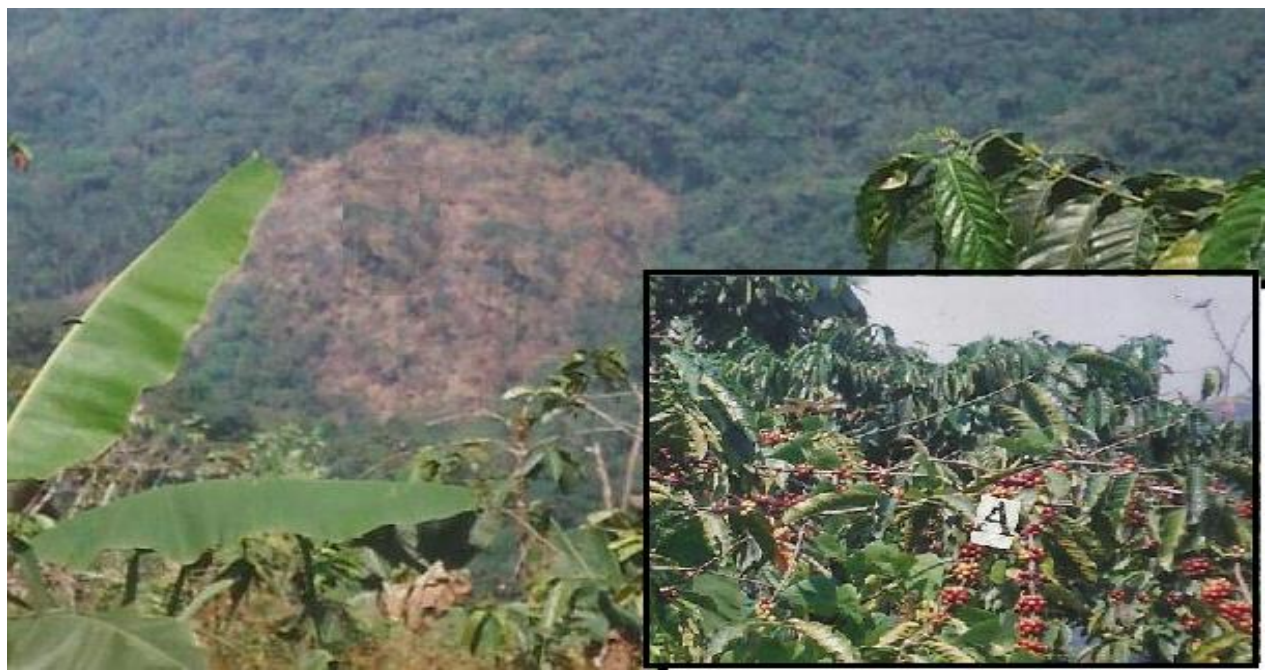

Plate 1: Creation of new coffee farm at the lower slope of Bamboutos mountains (1980s) Source: Azemafac phto 1999

In the mid-1980s, the Cameroonian economy entered a recession due mainly to the fall in world prices of the main export products: coffee, cocoa and petroleum. Most of the development structures created by the state go bankrupt. In West Cameroon, the UCCAO, which thus derived its resources from the sale of Arabica coffee, is experiencing financial problems and its supervisory activities are slowing down. The State adopts a so-called policy of disengagement from activities previously undertaken in favor of the rural world: supply of agricultural inputs, technical advice, marketing. The agricultural sector then experienced liberalization amid the abandonment of support from public funds. This contributes to putting an end to the monopoly held by the UCCAO for these questions in West Cameroon.

The period after the economic crisis was marked by several changes which affected the actors of the agricultural sector in the Western highlands of Cameroon: - the collapse of the coffee economy has led farmers to gradually diversify their production (Janin, 1996; Kamga, 2002). Coffes stems are witnessed been uprooting for the cultivation of highly demanded crops (Foko, 1999; Kamga, 2002).

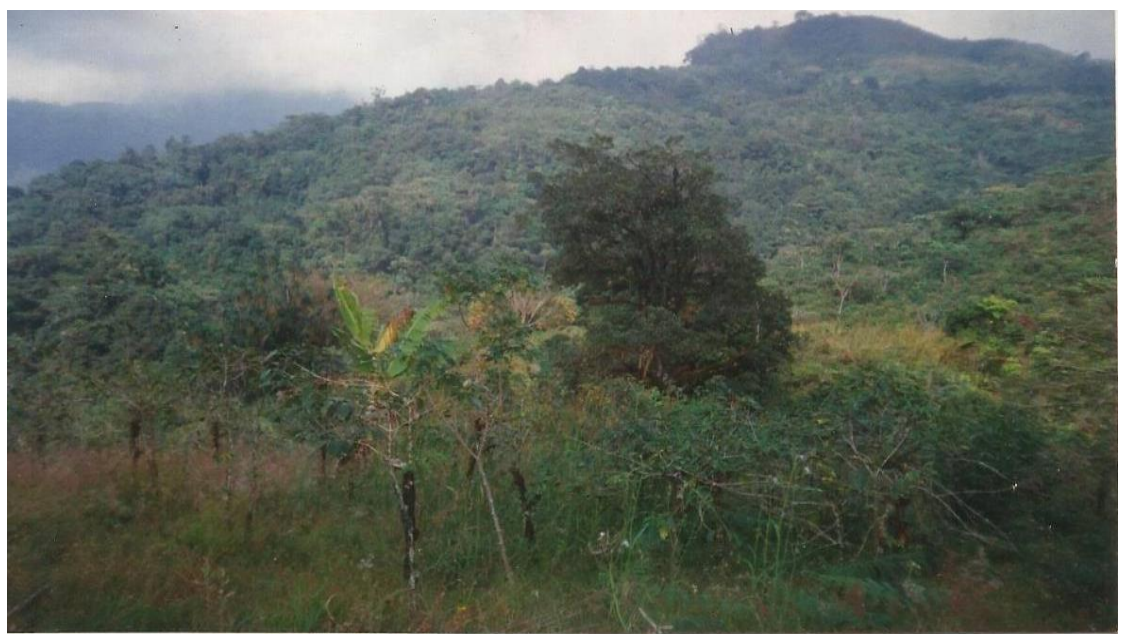

Plate 2: Abandoned Arabica coffee farm at the slope of bamboutos mountains Source: Azemafac, (1999) 
In replacement for the coffee which was a dominant crop, several other crops are grown and are intended for national and regional marketing in Central Africa including tomatoes, potatoes, corn, plantains, beans, etc. (Hatcheu Tchawé, 2000; 2006).

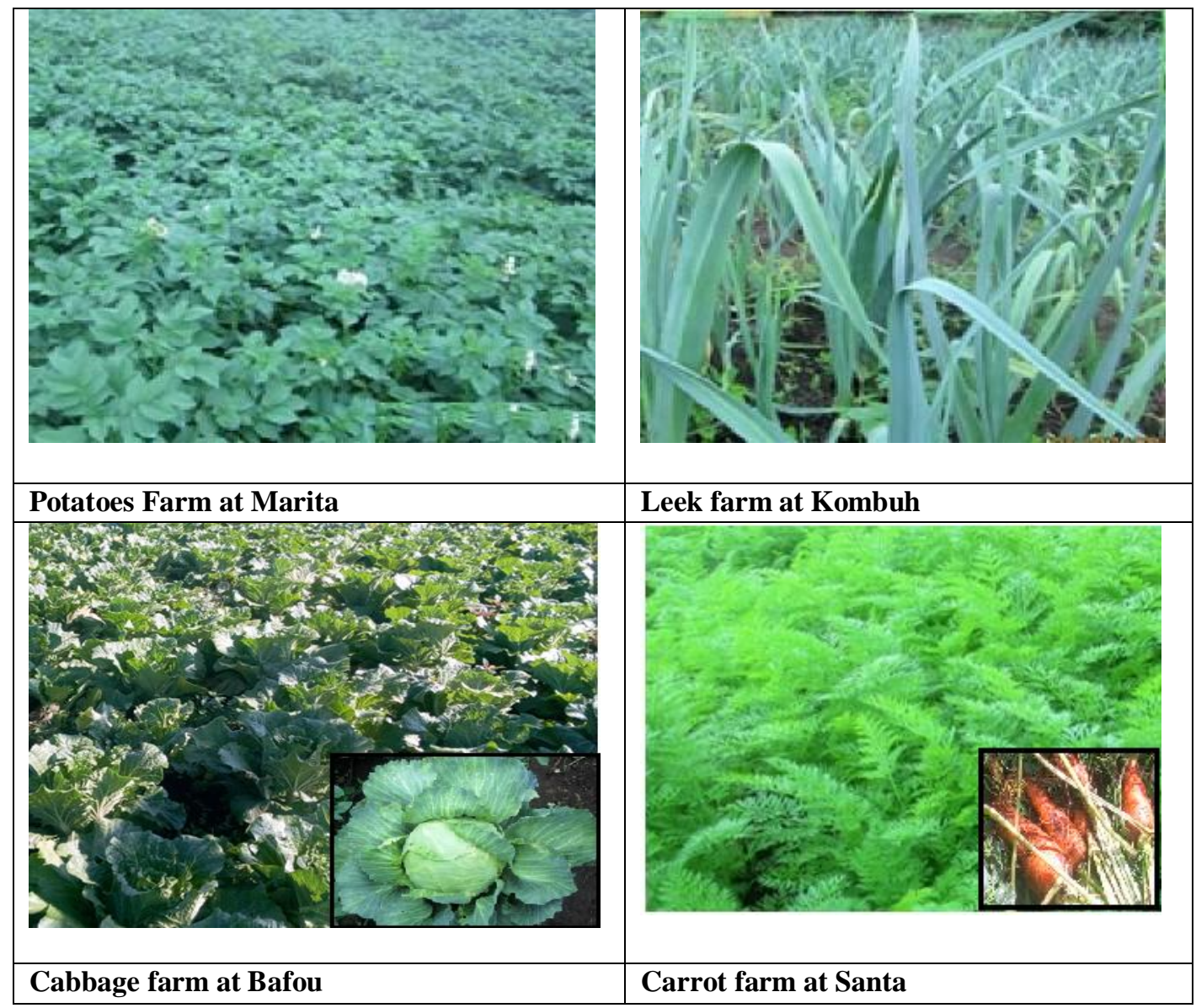

Plate 3: Main types of crops on different slopes of Bamboutos mountains Source: Field Work, (2019)

The agriculture practiced in the region has also undergone profound changes. The coffee tree no longer occupies a central place. New production systems have emerged (market gardening, corn, plantain, etc.), but are unable to provide the decent income and security that the coffee growing.In this context of change, there are profound social changes as well as a differentiation in peasant responses to the coffee crisis. This distinction is due to differences in their individual capacities which is described as composite capital combining technical know-how, economic capital, open-mindedness, level of education, physical strength, and potential for the environment. These qualities make a farmers very complete and there are described as typical profiles of farmers.

\section{METHODOLOGY}

The present research article adopts a mix research design where use is made of both quantitative and qualitative variables. The research technique adopted is generally descriptive. Both primary and secondary Data were collected through field observation, interviews with stakeholders through an exploratory semi-directed method, use of focus group discussions at village/quarter and equally from documentary sources. Data were collected effectively from 162 respondents out of 200 targeted ( 81 percent).After collecting all the necessary data descriptive and inferential techniques were adopted. Regression analysis and correlation were conduct with the help of excel 2016 and using SPSS version 25. Results was presented in tables, charts, photographs and maps.

Upper slopes of Bamboutos Mountain are located in the Western High Plateau of Cameroon and it is located between latitude, $5^{\circ} 32^{\prime}$ and $5^{\circ} 51^{\prime}$ North of the equator and longitude, $9^{\circ} 56$ and $10^{\circ} 09^{\prime}$ East of the Greenwich Meridian. and extending from an altitude of $2000 \mathrm{~m}$ to $2700 \mathrm{~m}$ above sea level, is typical of a multi-agricultural production system in the western highlands of Cameroon. The zone covers part of the three Cameroon administrative regions: West region, South West region and North West region. Bamboutos Mountain is a large volcanic complex extending in a north east-south west direction for over $50 \mathrm{~km}$, with the highest peaks rising to $2,679 \mathrm{~m}$ around the rim of a caldera with diameter $10 \mathrm{~km}$. Lava dating gives ages from 23 to 6 million years ago, with a lower basaltic series and an upper series of trachytes, trachyphonolites and phonolites (Alan, 2001). 


\section{RESULTS AND DISCUSSION}

Results of socio-economic background of respondents, reviewed many respondents are within the active age group (25 to 65 years) with majority falling within the age of 25 and $45(45.9 \%)$ and this obviously influence the many and type of agricultural practice. Male farmers accounts for over $54.9 \%$ of which over $78 \%$ were married with polygamy dominating as the regime. Equally that $69.7 \%$ of farmers are holder of FSLC.

Crops cultivated at the upper slopes of BamboutosMountain region include food crops such as potatoes, cocoyam, Maize and exotic vegetables carrot, cabbage and green pepper. Cash crops such as Arabica coffee have long been abandoned. The type of crops grown depends largely on regular supply of income, fertility of land, profit generated, and farmer's knowledge of crop and for posterity (cash crops). Farm produce are sold at the farm, in the communities, in the markets withon the BamboutosMountains area and at some markets outside the region such as in Dschang, Bafoussam and beyond to get better prices. Since most crops are perishable, they are sold right after harvest and only garlics and beans are stored in barns to be sold at a higher price in the lean season. Land cultivated for farming belonged to either family (74.6\%) or rented $(25.4 \%)$. With regards to farm labour used, majority of large scale farmers used hired labour especially on the western slope of the mountain around the Mmuock and Bafou communities (field survey, 2018).

\section{A. Types of crops cultivated by farmers}

Most of the farmers are engaged in the cultivation of food crops

\begin{tabular}{|c|c|c|}
\hline Types of farmers & Number in sample population & Percentages \\
\hline Food crop farmers & 23 & 14.2 \\
\hline Cash crop farmers & 56 & 34.6 \\
\hline Food crop and Cash crop farmers & 83 & 51.2 \\
\hline Total & 162 & 100.0 \\
\hline
\end{tabular}

Table 1:- Types of crops cultivated by farmers

In the eight communities where data were collected on the Bamboutos Mountains, majority were engaged in both food and cash crop farming (over 51\%). . Regarding the type of crop cultivate on the Bamboutos area. Six top ranking types of crops cultivated from field observation and interview include Irish potatoes, carrots, cabbages, leeks, green pepper and celeries in that orders.

\section{B. Steps for Agricultural Practice by Farmerson the Bamboutos Mountains}

The agricultural cycle is the annual cycle of activities related to the growth and harvest of a crop. The main steps for agricultural practices include preparation of soil, sowing, adding manure and fertilizers, irrigation, harvesting and storage. Farmers, the following five stages of agricultural practices could be distinguished in our study area.

\section{$\checkmark$ First step is concerned with the choice of crops selection}

Farmer fist decide on what crop is more profitable, the potential market demand for this crop Is the crop suitable for the climate and land? What fertilizers would be required, quantities of such fertilizers and application timings. Has he the required infrastructure for irrigation or it has to be created and if so at what cost. How much can be grown on his land and what would be the average expected yield. Does the potential irrigation requirement fulfillment capacity exist? Availability of Disease resistant seeds and control methods for diseases and pests. What land preparation is required for this crop to be sown? Farmer would be well advised to consult the weather conditions and forecasts. How the harvest would be made, stored and marketed.

The second step focuses on method of land preparation.

After selecting the crop, the farmland suitable for this crop is prepared. The basic has always been to break the earth for the depth required by a particular seed to establish itself. Presently, almost everywhere in the world, farmers employ powered mechanical means e.g. tractors for tilling operations, though manual and animal tillage is also practiced in some parts due to local conditions. The tractors themselves come in different shapes and sizes.

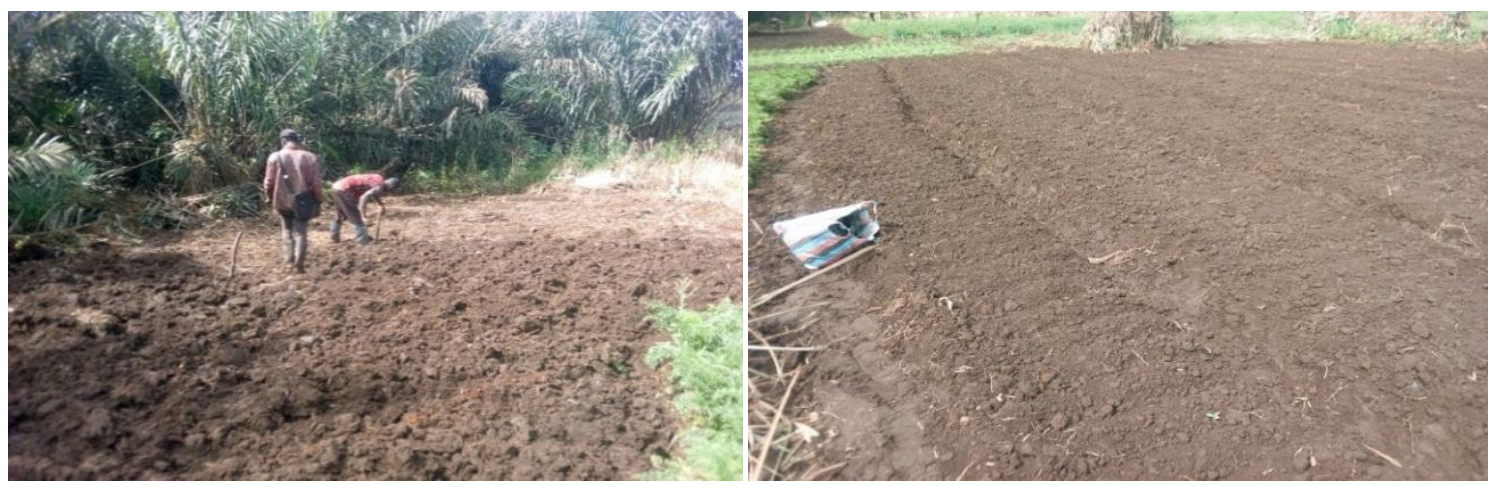

Plate 4; farm preparation on the Bamboutos mountains Source: Field Work, (2019) 
Tillage Practices starts with Ploughing - this is first pass of the tractor or manual effort over the soil so as to cut, break and invert the soil. Organic manures and full dose of phosphates are mixed with soil at this stage. Harrowing is the second step in tillage done to a shallow depth for smoothing and pulverizing the soil. Here weeds would be drawn out of soil and also mix fertilizers with the soil. This step would also bring soil moisture up. Leveling is the third step for improvement in value of land and to make arrangement for application of water, uniform moisture over the soil. A question arises what sort of tillageis required by the crop. Is it deep tillage, a shallow tillage, tillage with earlier crop residue still in the earth. Tillage is required to be done as it makes it softer for seeding of crops, uproot all weeds and old crop residues, permit irrigation water to go deeper, and equally helps in leveling and planning of the land.Mulch cover provides many benefits to the ground surface like it will prevent compaction of the soil, decrease virus and diseases of the plants, and not allow weeds to grow. The cost of land preparation is much less than in conventional tillage. Best benefit is that there is no burning of the crop residue which is highly detrimental to the environment and also harms the soil content as well friendly bacteria in the field.

\section{$>$ Planting of seeds is the third vital step of agricultural practice}

Cautions in planting of seeds include, the use of good quality seeds and treatment with chemicals so as to assist in easy germination. These are very essential aspects for the success of agricultural practices. Other important aspects involved in planting of seeds are to ensure that the Soil is moist and well compacted to enables that the seed gets the required moisture. Seeding must be done evenly and to the required density for that particular crop. Over seeding does not produce a good crop. Weed control chemicals need to be applied soon after seeding of the crop. Application of DAP di-ammonium-phosphate just below the seed is to be done.

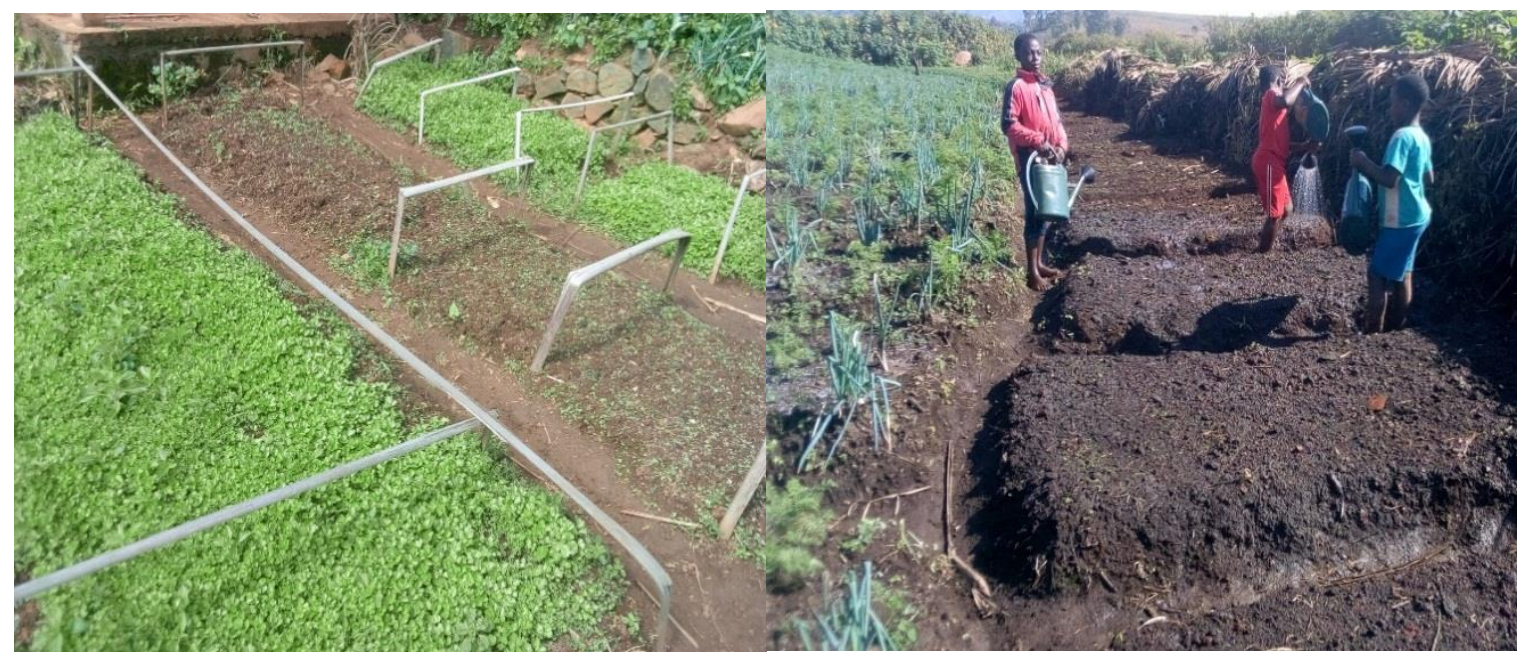

Plate 5: Nursing of seeds

Source: Field Work, (2019)

Other fertilizer like urea and some potassium should also be spread beforehand and watered. Another method of weed control using zero tilling and/or conservation tilling is to first make a false furrow in the ground. This will make weeds grow. Now apply chemicals to kill weeds. After this re-furrow and plant seeds.

\section{$>$ Forth step involves irrigation, fertilization and maintenance of crop growth}

After the seeds have sprouted, monitoring is needed of the moisture content in the soil so as to prevent any water stress in the plants. Irrigation is the process of artificially applying water to soil to allow plant growth. This term is preferably used when large amounts of water is applied to dry, arid regions in order to facilitate plant growth. The process of irrigation not only increases the growth rate of the plant bust also increments the yield amount.
In temperate and tropical areas rainfall and snowfall are the main suppliers of irrigation water, but in dry places with unfavourable weather conditions, groundwater serves as an essential source. Groundwater collects in basins made up of gravel and aquifers which are water-holding rocks. Dams also act as an essential distributive source of irrigation water. There are many ways how crops can be irrigated by applying artificial water drop by drop, sprinkling or applying the water on the entire field surface. There are two types of irrigation techniques: spray irrigation and drip irrigation. Drip irrigation is regarded more efficient as less water evaporated as in spray irrigation.

Once water stressed, plants become highly unproductive. Fertilizers need to be applied as per the need of the crop. To maintenance crop growth at different stages, defense against onset of any pests, virus is put in place. 


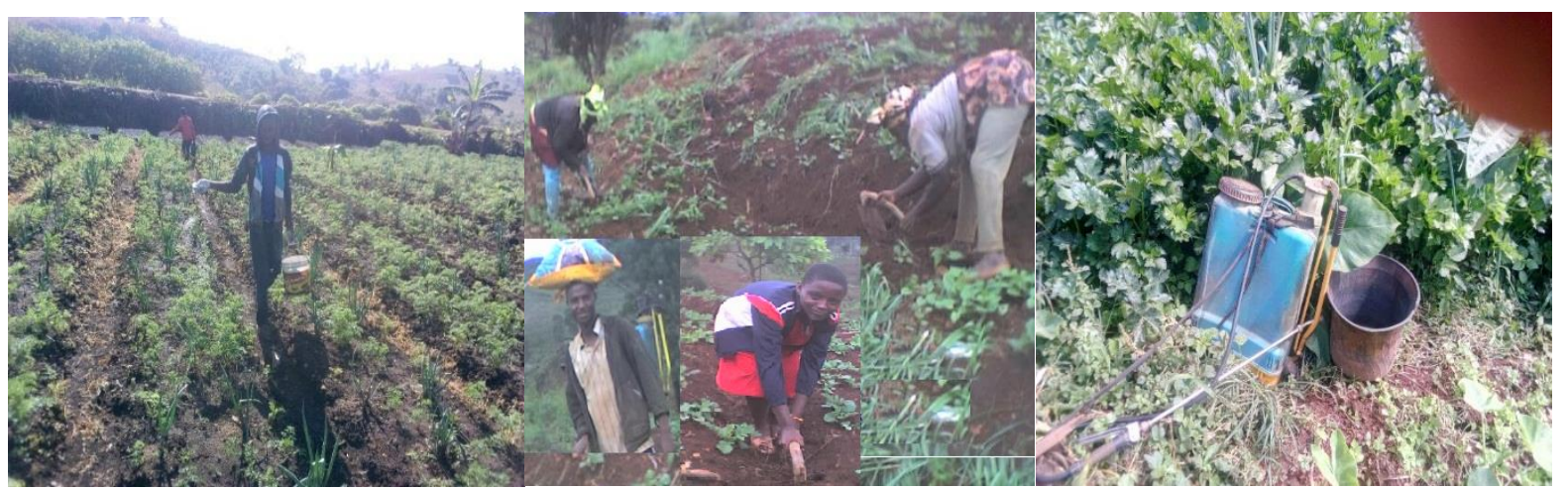

Plate 6: Fertilization, mulching and maintenance of crops growth Source: Field Work, (2019)

A good rule is to apply urea in three equal parts i.e. in the beginning of seeding and twice thereafter after the crop is growing. Phosphates are given once in the beginning. Potash may be required at later stages. Farmer would need to consult the advisory on crop basis.

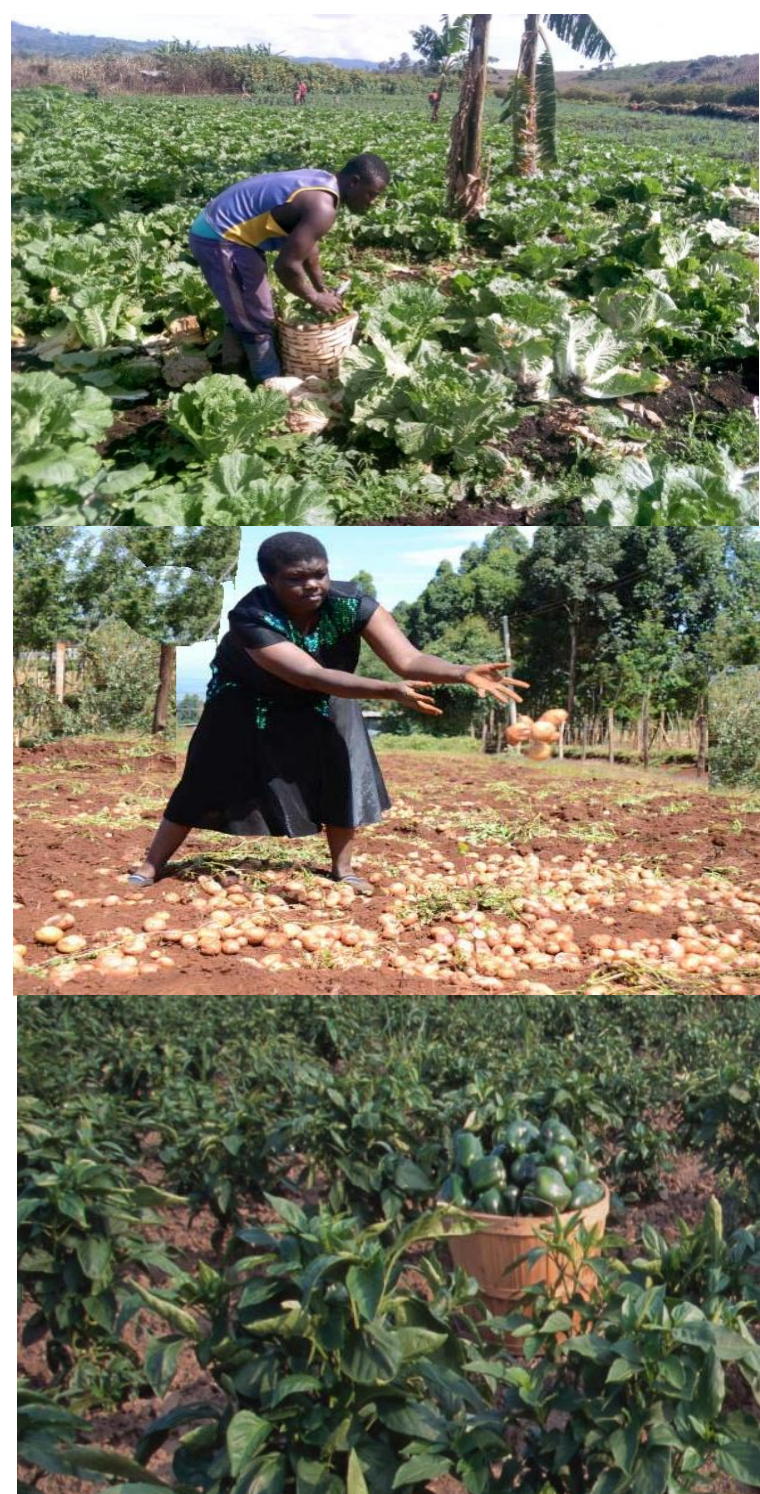

Plate 7: harvesting of crops (cabbages, beans, potatoes, leeks, poivron and carrots)

Source: Field Work, (2019)
$>$ The last step is on harvesting, Storage and Marketing

It is the end of the labors of the farmer and to realize the worth of his crop. Mechanical and manual methods to harvest are utilized depending on the resources at the command of the farmer and from country to country and place to place.

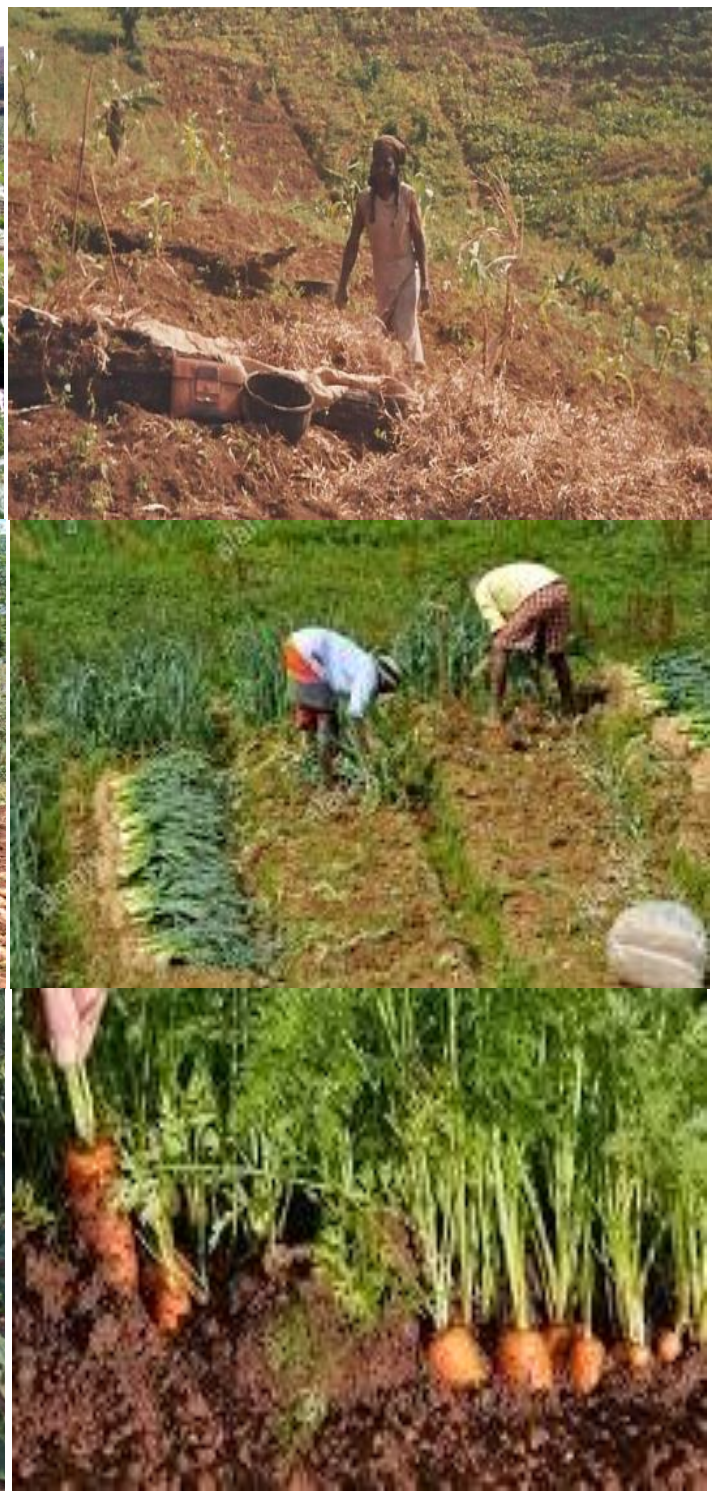


Repartition of agricultural zones on the upper slope of Bamboutos Mountains

Reparation of agricultural zone clarifies doubt of general types of crops at the different portion of Bamboutos

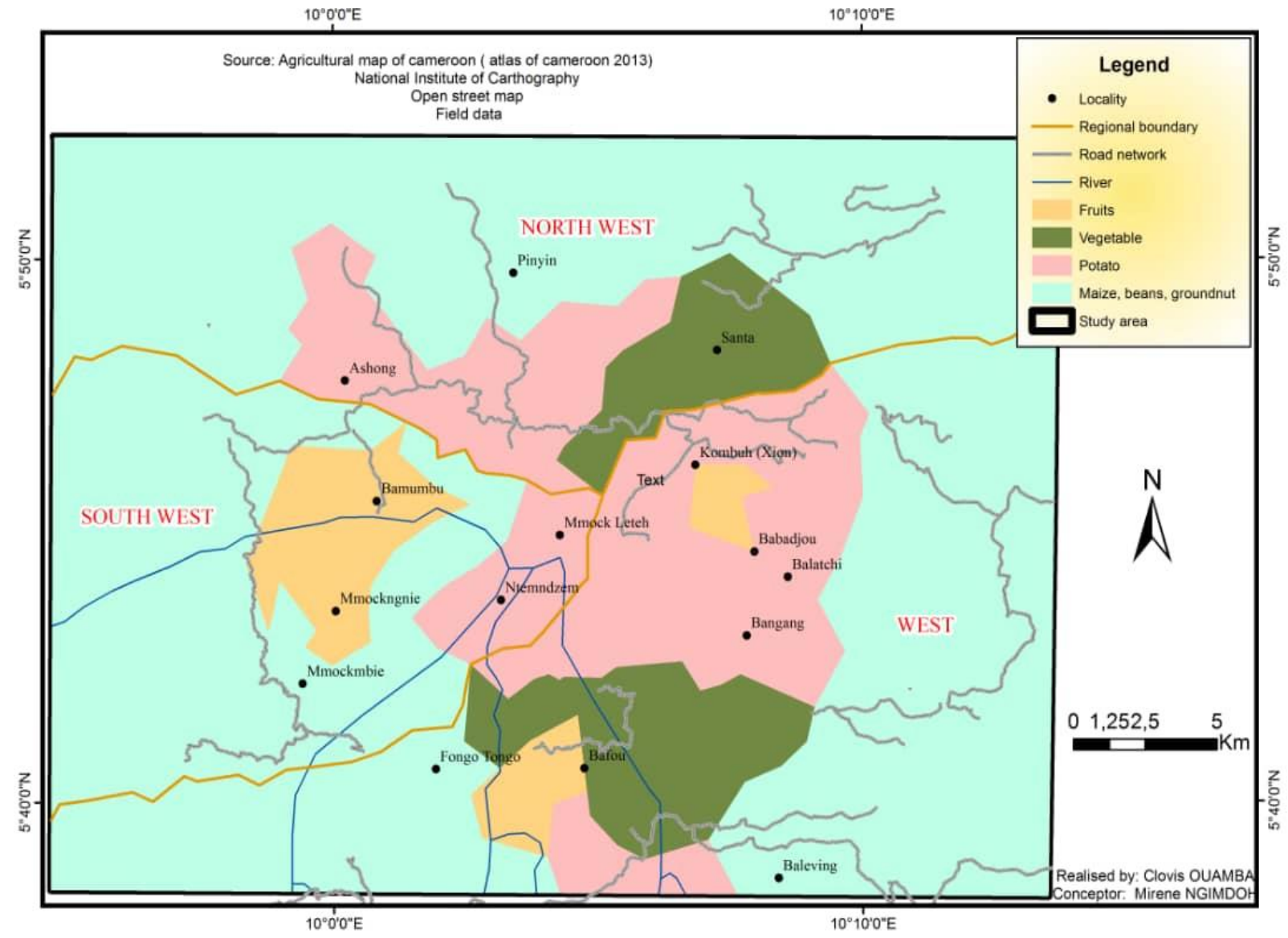

Fig 3: Repartition of agricultural zones on the upper slope of Bamboutos Mountains

Source: Agricultural map of Cameroon (atlas of Cameroon, 2013), National Institute of Cartography, Open street map data- field data

The result of the study presented by the map reveals that a dominants agriculture zone is that of potatoes, followed by that for vegetable and Fruit in that order.

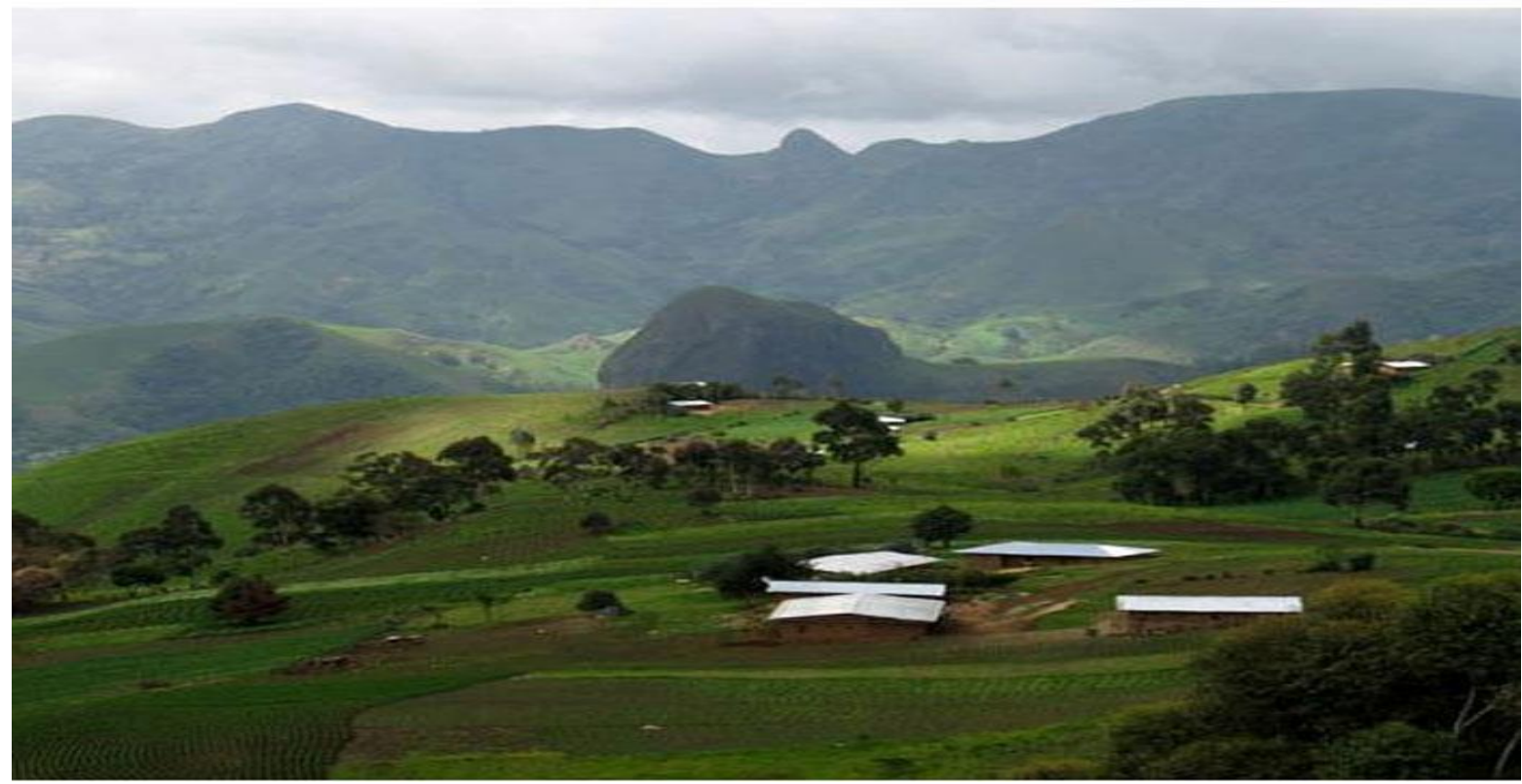

Plate 8: Partial view of farms around the residents Source: Field work (2018) 


\section{Relationship between farmers experience and farming practices}

To investigate the link between farmers' experience and extent of farm application, farm tools used and conservation methods applicable, Pearson correlation was used. The results depict and very significant but weak relations. A strong correlation is reported between farmers' experience and methods of preserving farm products with the coefficient of over $80 \%$ ( 0.839$)$ on the Bamboutos.

\begin{tabular}{|c|c|c|}
\hline \multicolumn{2}{|c|}{ Pearson Correlations } & Year of starting the activities \\
\hline \multirow{3}{*}{ Application of chemical } & Pearson Correlation & $0.425^{* *}$ \\
\cline { 2 - 3 } & Sig. (2-tailed) & 0.000 \\
\cline { 2 - 3 } & $\mathrm{N}$ & $0.292^{* *}$ \\
\hline \multirow{2}{*}{ Types of farming tools used } & Pearson Correlation & 0.000 \\
\cline { 2 - 3 } & Sig. (2-tailed) & 162 \\
\cline { 2 - 3 } & $\mathrm{N}$ & $0.839^{* *}$ \\
\hline \multirow{2}{*}{ Conservation methods } & Pearson Correlation & 0.000 \\
\cline { 2 - 3 } & Sig. (2-tailed) & 162 \\
\cline { 2 - 3 } & $\mathrm{N}$ & \\
\hline
\end{tabular}

Table 2:- Pearson Correlation results of farmers experience with other variables

The results of Pearson correlation reported in the proceeding table revealed that farmers experienced captured by years of starting the activities is positive and significantly correlated with method of conserving farm products, types of farm tools used and applicability of chemicals. It is noticed that methods of conserving the crops is strongly related farmers experience. Ancient farmers (farmers with over 20 years of farming experience) better preserve their crops and suffer less from spoilage when prices are less attractive in the market than your farmers' colleagues. The linkage between the type/ method of applying chemicals and farmers experienced is weak (less than 0.5) just like the coefficient of correlation between farming tools and farming experience. This is explained by the fact than most young farmer are more educated and therefore have more knowledge of the application of chemical (good dosage, precautions, time and type of pesticides and fertilizers to apply) just like experience farmers.

\section{Results of agricultural techniques on the Bamboutos Mountains}

Almost all the farmers used at least one type of chemical. Field survey report that, $93.4 \%$ of the respondents used chemical on the Bamboutos area. This corresponds to 151 farmers. For crop rotation practices, the following table summarises the results.

\begin{tabular}{|c|c|c|}
\hline Crop rotation & Number of farmers & Percentage \\
\hline Frequently practised & 65 & 40.1 \\
\hline Practice rarely & 79 & 48.8 \\
\hline Not practiced at all & 18 & 11.1 \\
\hline Total & 162 & $100 \%$ \\
\hline
\end{tabular}

Table 3:- Agricultural techniques on the Bamboutos Mountains

The results of farming techniques on the extent of practice of crop rotation, summarized in percentages, shows that only $40 \%$ of the farmers in the area frequently rotate crops in their farms. Crops rotation has been identified as agricultural sustain ability measure, yet up to $48 \%$ of farmers on the Bamboutos area do practice it according to the results of this study. This is explained by lack of knowledge on the importance of this practiced, small farm sizes and equally due to lack of means.

\begin{tabular}{|c|c|c|c|c|}
\hline \multicolumn{5}{|c|}{ Correlations } \\
\hline & & & Crop rotation & Education attainment \\
\hline \multirow{6}{*}{$\begin{array}{l}\text { Spearman's } \\
\text { rho }\end{array}$} & \multirow[t]{3}{*}{ Crop rotation } & Correlation Coefficient & 1.000 & $0.285^{* *}$ \\
\hline & & Sig. (2-tailed) &. & 0.000 \\
\hline & & $\mathrm{N}$ & 162 & 162 \\
\hline & \multirow{3}{*}{$\begin{array}{l}\text { Education } \\
\text { attainment }\end{array}$} & Correlation Coefficient & $0.285^{\text {** }}$ & 1.000 \\
\hline & & Sig. (2-tailed) & 0.000 &. \\
\hline & & $\mathrm{N}$ & 162 & 162 \\
\hline
\end{tabular}

Table 4:- Spearman's rho coefficient for farm techniques and education

Spearman's rho coefficient has reported a weak rank correlation between farm techniques captured by crop rotation and level of education. Both educated and uneducated farmers behave the same way when it comes to crop rotation. 


\section{The nature of Farm inputs on the Bamboutos Massif area}

Agricultural inputs are products permitted for use in farming whichthey are usefully subdivided into three:Fertilizers and chemicals,seeds and planting materials, and machinery and equipment. The result the table above reveal that over 70 percent of farmers used both crude and modern tools on the Bamboutos Mountains.

\begin{tabular}{|c|c|c|}
\hline Types of tools used & Number of respondents & Percentage \\
\hline Local or Crude & 33 & 20.3 \\
\hline Modern tools & 9 & 5.5 \\
\hline Both crude and modern tools & 121 & 74.2 \\
\hline
\end{tabular}

Table 5: Nature of farm tools used on the Bamboutos Mountains

Utilizing only modern tools is farfetched due to lack of capital one part and poor terrain on the other hand. The terrain cannot support the use of tractors which could facilitate agricultural process even if there are means to acquire such machine. Evidence can be seen from the partial view of the BamboutosMountain in the figure below.

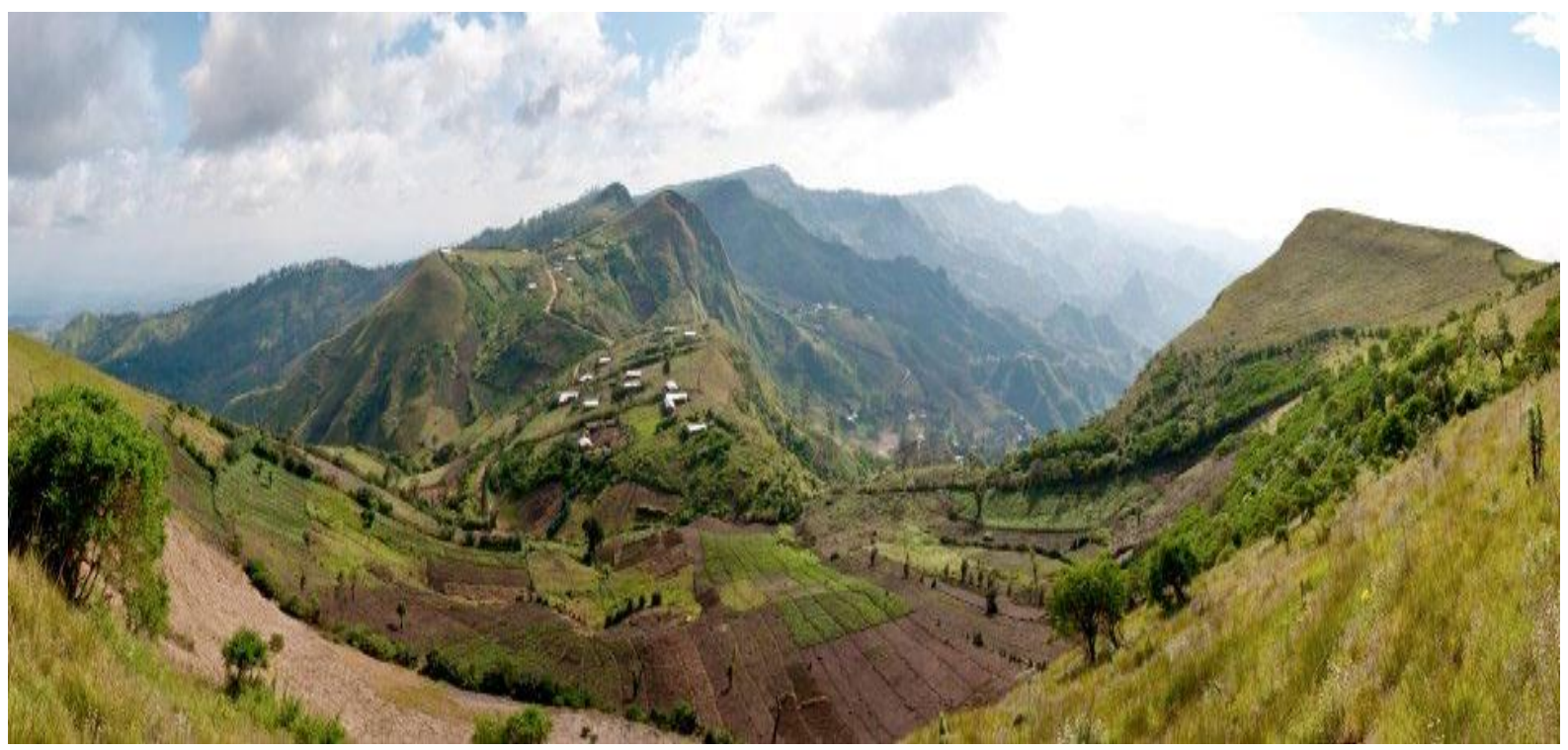

Plate 9: partial view of faring at the crest of Mount Bamboutos

Source: Field work (2018)

Partial view of agricultural farms shows that farm sizes are small and cultivated on the slope. Due to the three main constraints (rough terrain, financial needs and small farm sizes), majority of the farmers used both rudimentary tools and modern but not sophisticated tools and farming system is partly subsistence and commercial.

\section{Regression model of Agricultural practice on the Bamboutos Mountains}

Agricultural practice is captured in the ongoing research using the Practice of mixed cropping and also using Practice of Crops rotation.

\begin{tabular}{|c|c|c|c|c|}
\hline \multirow[b]{3}{*}{ Independent Variables } & \multicolumn{4}{|c|}{$\begin{array}{l}\text { Agricultural practice variables } \\
\end{array}$} \\
\hline & \multicolumn{2}{|c|}{ Practice of mixed cropping } & \multicolumn{2}{|c|}{ Practice of Crops rotation } \\
\hline & Coefficients & p- values & Coefficients & p-value \\
\hline Constant & $0.606^{* * *}$ & 0.001 & $0.751^{* * *}$ & 0.000 \\
\hline Education attainment & $0.273^{* * *}$ & 0.001 & $-0.125^{* *}$ & 0.014 \\
\hline Farmer's experience & $0.212^{* * *}$ & 0.001 & $0.319^{* * *}$ & 0.001 \\
\hline Parcels of land cultivated & -0.006 & 0.895 & -0.121 & 0.253 \\
\hline Agricultural profitability & $-0.071^{* * *}$ & 0.003 & $0.129^{* *}$ & 0.023 \\
\hline R-squared & 0.853 & & $0.513^{\mathrm{a}}$ & \\
\hline Adjusted R-squared & 0.849 & & 0.263 & \\
\hline F-stat (from ANOVA table) & $227.542^{* * *}$ & 0.001 & $14.006^{* * * *}$ & 0.001 \\
\hline S.E. of regression & 0.168 & & 0.041 & \\
\hline
\end{tabular}

Table 6: Regression model of Agricultural practice

Note: The superscripts $* * *$, and $* *$ indicate levels of significance at $1 \%$, and $5 \%$ respectively 
Fisher statistics for both indicators of agricultural practices used in this thesis were reported to very significant at $99 \%$ confidence level and $1 \%$ significant level as the calculated F-value is greater than the critical value implying that the model is significant in explaining the relationship. The regression results of the agricultural practice captured by the practice of mixed cropping on the Bamboutos Mountain is globally significant and adequate as $84.9 \%$ of variations in the model is explained by the independent variables. Agricultural practice model proxy by practice of crop rotation is highly significant but only $26 \%$ of variations in the model is explained by the independent variables meaning that the model is not really adequate.

Education attainment, Farmer's experience, and Agricultural profitability are identified as significant correlates of agricultural practices on the BamboutosMountainswith all the variables displaying the hypothesized positive relation except the variable for agriculture profitable captured quantitatively through Likert scale. Two variables: Sex of respondent and purpose of agriculture were dropped to improve on the adequacy of the model.

\section{E. Specific and general problems of agricultural practices on the Bamboutos Mountains}

From the interview and questionnaire issued to the delegate of agriculture and rural development, environment and local authorities in the month April 2019 in the different part of the study area (Bamboutos Mountains), a snap shot of the following problem and suggested solutions were gathered.

Regarding the specific Problems of agricultural practices on the Bamboutos, we noticed that, frequent conflict between farmers and grazers (agropastoral problem) on the Bamboutos Mountains is one of the specific problems as is the case of Bacham and Galim sub divison where cows, goats and ship from Bacham eat and destroy carrot, corn and pear in Galim, like wise a similar problem is witnessed in upper Bafou and Marita where cattle constantly invade carrot, potatoes and cabbage farms.

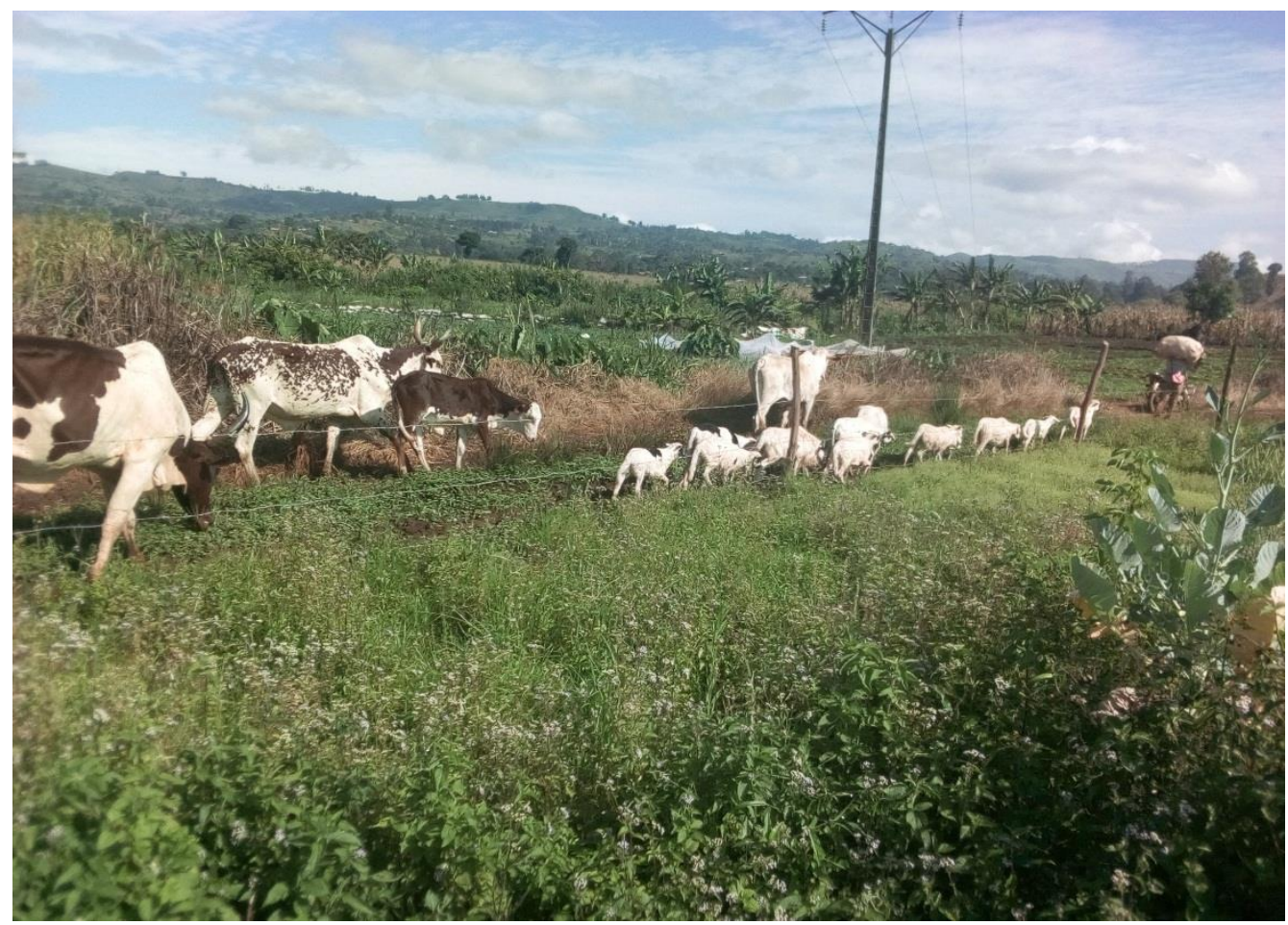

Plate 10: Farmer- Grazer problem in Komboh)

Source: Field Work, (2019)

Insecurity that mount fear on farmers in the Mmock zone of the Lebialem division, Matazem in Babadjou Subdivision and Pinyin is the santa subdivision and Fimmock in the Bafou (koungni subvision), where farmers are constantly been killed, kidnapped or intimidated in farms. Also, flooding is another problem witnessed in the Kombuh locality especially at the Damaniac plains. The plain experiences a lot of flood which has caused serious damage in many hectares of farms in the area.

The general problems of agricultural practices on the Bamboutos are numerous. A greater number of farmers on the Bamboutos mountain zone are resistant to change due to their consecutive or primitive nature. Despite the advice and number of seminars agric-technicians organized to sensitize farmers on more sustainable farming techniques all across the area, the rate of adaption or assimilation remain very insignificant.

Also, there is the problem of inadequate high yielding and more resistance seeds to satisfy the demands of the population especially the demand for carrots, potatoes, corn, and beans seeds. Despite all the effort put in place by the Government to provide these as a strategy to boost 
agricultural productivity in the area and Cameroon at large, less than two-third of demand by farmers is satisfied.

The expensive nature of farm input ranging from chemical fertilizer, fowl dropping and others which are heavily used on the Bamboutos agricultural zone is another serious problem in this zone. The problem is compounded by falling prices of agricultural product. It is noticed that since the advent of bird flow in Cameroon, poultry farming has not yet regained its stability creating shortage in the supply of it bi-product (fowl dropping) couple with crisis in north West region which use to provide a steady market for fowls.

Shortage of government budget is a great obstacle in realizing their earmarked annual projects and on time. As a consequence, most farms to market remain impracticable for over years thereby increasing the cost of farming in such locality with the end results being to abandon the farm unwillingly.
Difficulties in mechanizing agricultural practices on the Bamboutos area reduce farmers' productivity, increase labour cost, and sometime over stress up farmers in the process. It was noticed from the questionnaire dished out to various delegations in the area that the main obstacle to mechanization of farming process on Bamboutos Mountains is not just the problem of inadequate capital as it may be believed from the first sight but rather that of the accidental nature of the terrain in some areas, narrow and hilly natures of farm roads in other areas and small farm holdings in almost the whole Bamboutos Mountains farming zone.

The topographical map in figure (4) shows clearly that the hilly nature of the upper slopes of the mountain (above $2000 \mathrm{~m}$ above sea level) where are our study focused posed serious problems on the use mechanized farming method, quick and efficient means of transporting farm inputs, labour and output, and exposes the farms to high rate of erosion.

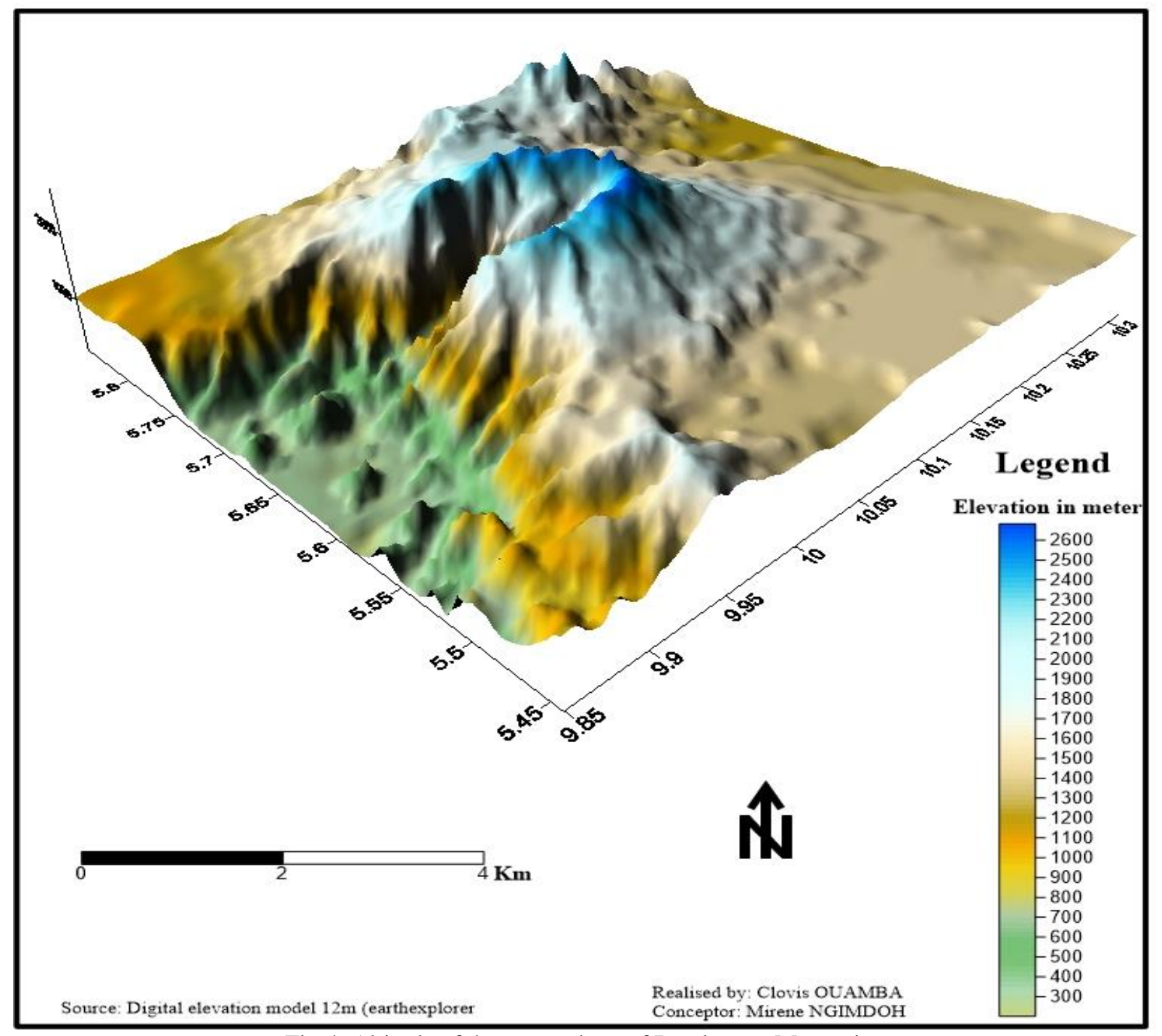

Fig 4: Altitude of the upper slope of Bamboutos Mountains Source: Digital elevation model 12m (earth explorer). 
Farmers do not equally have access to credit. Banks on their part shy from financing agricultural activities, as, farming is considered a very risky business venture whose success relies so much on weather conditions and worse still, one can never predict its proceeds in advance. The farmers on their part face difficulties in obtaining loans from the bank which is very necessary to intensive, expand or mitigate pests due to inadequate, inappropriate or absent of collateral security. In the Garoua agric show, few years back, the government did promise the establishment of agricultural bank which is still hanging. Most farmers resort to Njangi houses which does not meet up with up to twenty percent farmers' desires in term of quality of service rendered and amount of fund needed.

Over farming due to high population pressure on farm leads to loss of soil fertility in the area. Over grazing or cultivation of same piece of land over many years with little knowledge of agricultural sustainability exposes the soil to great danger. As iterated by the delegate of agriculture and rural development of Bamboutos division, salary cut in public service as one of the structural adjustment program in Cameroon in the 1990s forced civil servants to farms where Bamboutos Mountains fertile soil attracted many. Since then, this area has been farmed continuously up to the margin lands which has greatly depleted the soils coupled with climate change.

The elites in some of the area have monopolised almost all the farm plots which posed a major problem to the youths. An attempt to acquire part of the plot for farming in any form (purchase, lease, rent, beg) sometimes end through court action. It is shared and cultivated by relatives and where the instructions are not strictly respected, it is forcefully allowed to fallow (land tenure obstacle).

Another serious problem especially on the part of MINADER is that of insufficient personnels, inadequate materials/equipment, poor communication (language problems).

As proposed Solutions to the problems plaguing agricultural practices, first, the government should reduce cost on modified seeds, chemical fertilizers and other essential farm inputs by giving subvention or direct material or financial assistance to farmers in the area.The government should create special banks meant only for farmers and make the banks effective for it to suit each farmer's level and specialty.

The government should disenclave some agricultural zone by digging, enlarging, and maintaining farms paths or routes by making them more accessible all year round. This is the case of Guaya and Bamock areas with vast fertile land but it enclaves nature, characterized with poor routes hinder effective agricultural practices.

Government should put in place the training and the recruitment of personnels in order to increase the farmerstechnician's ratio. Example, on the Bamboutos division, there is a total of 40 personnels which is less than one- third of the 180 needed.The government should equally apply agricultural reforms like structural adjustment programs in order to resolve some of these problems.

To enable the young able farmers, have access to farm land or plots, one of the delegate gave as suggestion that, age limit has to be removed for the acquisition of land titles. This will go a long way to reduce the ill of land tenure, ration land to optimal use and thus boost agricultural productivity on the Bamboutos Mountains.

\section{CONCLUSION}

The objective of this paper was to explore the logic of agricultural practices on the Bamboutos Massif area. The upper slopes of the Bamboutos Mountainscut across three administrative regions of Cameroon including the South West, West and North West regions. Agricultural practices have been the likelihood of the Bamboutos Mountains population, thanks to its rich and vast area of fertilize soil and lack of alternative means of subsistence.

After developing a conceptual framework that reviews the key concepts and theories of agricultural practices. Both primary and secondary data were collected from the eight localities which constitute the area under study. Multistage sampling technique constituting of the cluster sampling, stratified sampling and random sampling methods were jointly used to target a sample of 200 of which 162 were effectively collected. The data were analyzed with the help of SPSS version 25 and Excels 2016 and presented in tables, charts and graphs. Statistical tests conducted include correlation testing, regression analysis and Fischer test.

Results of the study revealed that the modal age group of farmers in the locality is 30-40 years, 69 percent of respondents are holders of just FSLC and agriculture is instead practiced mainly by male population (55\%) and majority of the farmers are married.Majority of the farmers have many year of farming experience which has be statistically tested to have positive and significant correlation with method of consuming farm product, farm tools used and prudence in apply chemicals. On other agriculturally practice, it was found that only 40 percent of the farmers practice crop rotation, bush fallowing method was very negligible and finally it was noticed that 74 percent of the farmers used both modern tools and crude tools in the locality.

Result of regression model of farm practice captured by practice of crop rotation and mixed farming is significantly and positively influenced by education attainment of farmers, farmers experienced but negatively affected by profitability. The results of the article show that over 70 percent of farmers used both crude and modern tools on the Bamboutos Mountains. It was also noticed that farmers experienced has a positive and significant correlation with method of conserving farm products, types of farm tools used and applicability of chemicals but a weak rank correlation between crop rotation and level of education. 
Field data permit us to identify a good number of problems plaguing the agricultural practice on the BamboutosMountain ranging from specific problem such as frequent conflict between farmers and grazers, and insecurity that mount fear on farmers in the localities of Mmock, Matazem Matazem and Pinyin. general problems were identified as resistance of farmers to adapt to new techniques, inadequate yielding and more resistance seeds, expensive nature of farm input, poor farms to market tracks, difficulties in mechanizing agricultural practices, inaccessibility of Farmers to sizable credit, Over farming due to high population pressure on farm and insufficient personnels on the part of MINADER.

\section{REFERENCES}

[1]. AdityaH., (2013) five Main Impacts of Agriculture on Environment, unpublished article

[2]. Aksoy, M. A. (2005), "The Evolution of Agricultural Trade Flows", in Global Agricultural Trade and Developing Countries. M.A. Aksoy and J.C. Beghin eds. Washington D.C.: The World Bank. Simmons, P. 2003. "Overview of Smallholder Contract Farming in Developing Countries", Rome: FAO. ESA Working Paper No. 02-04.

[3]. Alan R. W., (2001)."Bambouto". Alkaline rocks and carbonatites of the world, Part 3. Geological Society. p. 35. ISBN 1-86239-083-5.

[4]. Bouville, M., (2014), Comparing the different types of agricultural practices Various Agriculture Farming Loans For Farmers in IndiaFebruary 28, 2018In "Loans and Subsidies" Types of Modern Technology in Agriculture in IndiaJanuary 29, 2018In "Technology"

[5]. Courade G., .(1988).Organisations paysannes, société rurale, Etat et Développement au Cameroun 19601980. ORSTOM, Paris.vol.2, 831p.

[6]. Dilip Chandra (2011),Agriculture \& Farmingtypes. unpublished

[7]. Dufumier M. (1985). Systèmes de production et développement agricole dans le Tiers Monde. Montpellier, Revue Les cahiers de la Recherche Développement,

[8]. Dufumier M. (1985). Systèmes de production et développement agricole dans le Tiers Monde. Montpellier, Revue Les cahiers de la Recherche Développement,

[9]. Engola O. J. (1984). L'approche intégrée du développement rural auCameroun. In Actes $d u$ séminaire sur les organismes d'intervention en milieu rural dans le processus de développement Vol 2. Dschang, Centre Universitaire de Dschang, p. 173182.

[10]. Epstein E. (1972). Mineral Nutrition of Plants: Principles and Perspectives. Whitley, New York, 412 p.

[11]. Eva Perroni (2017), "Five Indigenous Farming Practices Enhancing Food Security", Food Tank

[12]. FAO. (2020).Irrigation potential in Africa: a basin approach. Available from
[13]. FAO. 2020. "Aids a Threat to Rural Africa". Rome: FAO.

[14]. Foko E. (1999). Le café arabica dans le système de production agricole de l'Ouest du Cameroun. Cahiers d'études et de recherches francophones / Agricultures. Volume 8, Numéro 3, p. 197-202.

[15]. Ghanem, M. Samhan, S. Carlier E. and Ali, W. (2011)“Groundwater Pollution Due to Pesticides and Heavy Metals in North West Bank," Journal of Environmental Protection, Vol. 2, , pp. 429-434. http://dx.doi.org/10.4236/jep.2011.24049

[16]. Gountié Dedzo M, Njonfang E, Nono A, Kamgang P, Zangmo Tefogoum G, Kagou Dongmo A, Nkouathio $D G$. (2012). Dynamic and evolution of the Mounts Bamboutos and Bamenda calderas by study of ignimbritic deposits (West-Cameroon, Cameroon Line) Syllabus Review 3: $11-23$.

[17]. Hatcheu T. E., (2006).Marchés et marchands de vivres à Douala. L'Harmattan, Collection Mouvements Economiques et Sociaux, $189 \mathrm{p}$.

[18]. Hazell, P. 2009. "Transformation in Agriculture and the Impacts on Rural Development", Beyond Agriculture: the promise of the rural economy for growth and poverty reduction. Rome: FAO.

[19]. Janin P. (1999).L'avenir des planteurs camerounais. Paris, Karthala.

[20]. Jeff Waage(2010) Bringing agriculture and health back together, Integrative Research on Agriculture and Health.

[21]. Kagou Dongmo A, Nkouathio DG, Pouclet A, Bardintzeff JM, Wandji P, Nono A, Guillou H. 2010. The discovery of Late Quaternary basalt on Mount Bambouto: implications for recent widespread volcanic activity in the southern Cameroon Line. Journal of African Earth Sciences 57: 87-108.

[22]. Kamga A. (2002). Crise économique, retour des migrants, et évolution du système agraire sur les versants oriental et méridional des monts Bamboutos (Ouest Cameroun). Thèse de doctorat, Université de Toulouse - Le Mirail, Toulouse, 311 p.

[23]. Kuete M. and Dikoume A. (2000).Espace, pouvoir et conflits dans les hautes terres de l'Ouest Cameroun.Presse universitaire de Yaoundé. 149p.

[24]. Marzoli A, Renne PR, Piccirillo EM, Francesca C, Bellieni G, Melfi AJ, Nyobe JB, N'ni J. (1999). Silicic magmas from the continental Cameroon volcanic line (Oku, Bambouto and Ngaoundéré): 40Ar/39Ar dates, petrology, Sr-Nd-O isotopes and their petrogenetic significance. Contributions to Mineralogy and

[25]. Morin S. (1988). Les dissymétries fondamentales des Hautes Terres de l'Ouest-Cameroun et leurs conséquences sur l'occupation humaine. Exemple des Monts Bambouto. L'homme et la montagne tropicale. Sépanrit ed ; Bordeaux. pp 49-51.

[26]. Ngoufo R. (1988). Les monts Bambouto. Environnement et utilisation de l'espace. Thèse de Doctorat $3^{\text {ème }}$ cycle, Universté de Yaoundé, Vol. I, 349 p, Vol. II, 25 p. 
[27]. Ngoufo R., (1992), the Bamboutos mountains: Environment and Rural Land Use in West Cameroon. Mountains Research and Development, 12(04): 349356

[28]. Nkouathio DG, Kagou Dongmo A, Bardintzeff J-M, Wandji P, Bellon H, Pouclet A. (2008). Evolution of volcanism in graben and horst structures along the Cenozoic Cameroon Line (Africa): implications for tectonic evolution and mantle source composition. Mineralogy and Petrology 94: 287-303

[29]. Nono A, Njonfang E, Kagou Dongmo A, Nkouathio DG, Tchoua FM. (2004). Pyroclastic deposits of the Bambouto Volcano (Cameroon Line, Central Africa): Evidence of a strombolian initial phase. Journal of African Earth Sciences 39: 409-414.

[30]. Swinnen, J. and M. Maertens. 2006. "Globalization, Privatization, and Vertical Coordination in Food Value Chains in Developing and Transition Countries", Plenary Session on "Trade and Marketing of Agricultural Commodities in a Globalizing World" at the 26th Conference of the International Association of Agricultural Economists: Queensland, Australia.

[31]. Syed Asif (2018), Different Types of Agricultural Practices/Different Types of AgricultureIndia, Various Agriculture Farming Loans For Farmers in IndiaFebruary 28, 2018In "Loans and Subsidies" in "Technology"

[32]. Tematio P, Olson KR. (1997). Impacts of industrialized agriculture on land in Bafou, Cameroon. Journal of Soil and Water Conservation 52: 404-405.

[33]. Topouzis, D. (1999), "Sustainable Agricultural/Rural Development and Vulnerability to the Aids Epidemic", Geneva: UNAIDS/FAO, Best Practice Paper. www.unaids.org.

[34]. Tsozué D. and Tamfuh A. P., (2016), Physicochemical characteristics, degradation rate and vulnerability potential of Mount Bambouto soils in Western Highlands of Cameroon. Syllabus Review, Science Series 6: 46 - 57 ISSN 2409-319X

[35]. Wilfred A. A., Conalius E. S.,Richard F., and Markjovert T. A. (2016), "Agriculture In Cameroon: Proposed Strategies To Sustain Productivity". University of Yaounde I, Cameroon

[36]. Youmen, D. (1994) Evolution volcanologique, pétrologique et temporelle de la caldeira des monts Bambouto (Cameroun). Thèse, Christian-AlbrechtsUniversitat zu Kiel, Kiel, Allemagne, 274 p. [Citation Time(s):1] 